\title{
Importance of health guidance for family members of children with sickle cell disease
}

\author{
Importância das orientações em saúde para familiares de crianças com doença falciforme \\ Importancia de las orientaciones en salud para familiares de niños con enfermedad falciforme
}

\author{
Sarah Vieira Figueiredo', Letícia Alexandre Lima', Débora Pena Batista e Silva', \\ Raquel de Maria Carvalho Oliveira', Macedônia Pinto dos Santos', Ilvana Lima Verde Gomes' \\ 'Universidade Estadual do Ceará. Fortaleza, Ceará, Brazil.
}

How to cite this article:

Figueiredo SV, Lima LA, Silva DPB, Oliveira RMC, Santos MP, Gomes ILV. Importance of health guidance for family members of children with sickle cell disease. Rev Bras Enferm [Internet]. 2018;71(6):2974-82.

DOI: http://dx.doi.org/10.1590/0034-7167-2017-0806

Submission: 12-13-2017

Approval: 04-03-2018

ABSTRACT

Objective: To know the main health guidance needs of family members of children with sickle cell disease. Method: Qualitative research, developed in a pediatric reference hospital of Ceará State, between April and May 2017, through the participation of 12 family members of children with sickle cell disease. The data were collected through semi-structured interviewees and analyzed according to the Bardin's Thematic Categorical Analysis. Results: The relatives had divergent opinions about what this pathology would be and expressed the expectation of being broadly guided, from general information (signs and symptoms) to more complex ones about the disease, including major complications and ways of preventing them. Final considerations: The health fragility due to the punctual and/or meager guidance provided to family members reflects the importance of increasing knowledge and clarifying doubts of these relatives about the disease, which makes it urgent to develop health education strategies by multiprofessional teams. Descriptors: Anemia, Sickle Cell; Child; Family; Health Education; Comprehensive Health Care.

\section{RESUMO}

Objetivo: Conhecer as principais necessidades de orientação em saúde de familiares de crianças com doença falciforme. Método: Pesquisa qualitativa, desenvolvida em um hospital de referência pediátrica no Ceará, entre abril e maio de 2017, mediante a participação de 12 familiares de crianças com doença falciforme. Os dados foram coletados por meio de entrevistadas semiestruturadas e analisados segundo a Análise Categorial Temática de Bardin. Resultados: Os familiares possuíam opiniões divergentes acerca do que seria essa patologia e expressaram expectativa de serem amplamente orientados, desde informações gerais (sinais e sintomas) até outras mais complexas sobre a doença, incluindo principais complicações e formas de prevenilas. Considerações finais: A fragilidade em saúde decorrente da pontual e/ou insuficiente orientação recebida pelos familiares reflete a importância de ampliar o conhecimento e sanar as dúvidas desses familiares sobre a doença, o que torna premente o desenvolvimento de estratégias de educação em saúde por equipes multiprofissionais.

Descritores: Anemia Falciforme; Criança; Família; Educação em Saúde; Assistência Integral à Saúde.

\section{RESUMEN}

Objetivo: Conocer las principales necesidades de orientación en salud de familiares de niños con enfermedad falciforme. Método: Investigación cualitativa, desarrollada en un hospital de referencia pediátrica en Ceará, entre abril y mayo de 2017 , mediante la participación de 12 familiares de niños con enfermedad falciforme. Los datos fueron recolectados por medio de entrevistadas semiestructuradas y analizadas según el análisis categorial temático de Bardin. Resultados: Los familiares tenían opiniones divergentes acerca de lo que sería esa patología y expresaron su expectativa de ser ampliamente orientados, desde informaciones generales (signos y síntomas) hasta otras más complejas sobre la enfermedad, incluyendo principales complicaciones y formas de prevenirlas. Consideraciónes finales: La fragilidad en salud derivada de la puntual y/o insuficiente 
orientación recibida por los familiares refleja la importancia de ampliar el conocimiento y sanar las dudas de esos familiares sobre la enfermedad, lo que hace urgente el desarrollo de estrategias de educación en salud por equipos multiprofesionales.

Descriptores: Anemia de Células Falciformes; Niño; Familia; Educación en Salud; Atención Integral de Salud.

\section{CORRESPONDING AUTHOR Sarah Vieira Figueiredo E-mail: sarahvfigueiredo@gmail.com}

\section{INTRODUCTION}

Hemoglobinopathies are a set of hereditary disorders related to genes responsible for the synthesis of globins. It is estimated that approximately $7 \%$ of the world population has hemoglobin-related $\mathrm{Hb}$ disorders, with sickle cell disease being the most prevalent hereditary disease in the world ${ }^{(1)}$. It is estimated that in Brazil an average of 3,000 people are born with this disease per year ${ }^{(2)}$.

Because it is a not notifiable disease, it is difficult to calculate the exact number of affected individuals. Thus, estimates are also made in other countries, such as the United States, where analyzes of different studies have shown that approximately 72,000 to 100,000 people have this disease ${ }^{(3-5)}$.

Sickle cell diseases are due to a mutation in the gene responsible for the production of $\mathrm{HbA}$, which results in the formation of a different $\mathrm{Hb}$, called $\mathrm{S}$, which has recessive inheritance. There may be other types of mutant hemoglobins, such as $C$, $\mathrm{D}, \mathrm{E}$, among others. Thus, the combinations of a mutant $\mathrm{Hb}$ with another of type $S$ constitute sickle diseases, with the most frequent being: sickle cell anemia ( $\mathrm{Hb} \mathrm{SS}$ ), S beta thalassemia and the double heterozygous $\mathrm{HbSC}$ and $\mathrm{HbSD}^{(2,6)}$.

In individuals presenting with this disease, the erythrocytes assume the shape of a scythe, which hinders adequate blood flow, generating processes of vaso-occlusion and infarcts in the affected areas. As a consequence, there is ischemia, pain, damage to various organs and tissues, necrosis and chronic hemolysis. In addition, the regional hypoxia process itself may intensify sickling of new erythrocytes, increasing ischemic damage ${ }^{(2,7-8)}$.

Taking into account that this disease has many physiological and clinical peculiarities, some situations require special attention regarding the occurrence of a possible crisis or serious complication. In such cases, it is necessary to intervene quickly and implement the appropriate therapies in order to prevent sequels and even early deaths; thus, families of children with sickle cell disease need to be guided on ways to avoid crises and behaviors to be adopted if they occur. They should also know what their health rights are guaranteed by the Unified Health System (SUS - Sistema Único de Saúde) and have clarified any other doubts that they may present throughout their lives.

In this perspective, a study by Fernandes and others ${ }^{(9)}$ showed, among other aspects, that the difficulty of families of children with sickle cell disease to identify risk situations contributes to infant death, sometimes even before arriving at the hospital. The authors concluded that it is essential to direct educational efforts to health professionals and family members, in order to reduce morbidity and mortality from this disease.

In research conducted in the capital of Lebanon, Beirut, health education interventions were carried out for caregivers of children with sickle cell anemia and statistical analyzes before and after this process. The results revealed that guidance and distribution activities of educational materials written in a language accessible to the target public are beneficial to increase the knowledge of caregivers, as well as contribute to the reduction of the number of hospitalizations ${ }^{(10)}$.

In this perspective, in order to contribute to a better functioning of the network of comprehensive care to sickle cell disease and to favor the process of health education for family members of children with this disease, the research group Chronic Diseases in Children and Adolescents, Family, Collective Health and Nursing (DOCAFS - Doenças Crônicas em Crianças e Adolescentes, Família, Saúde Coletiva e Enfermagem) of the Universidade Estadual do Ceará (UECE) has been developing, since 2016, a research whose objective is to develop an educational technology that provides guidance to family members of these children.

It is worth noting that the imbalance resulting from sickle cell disease significantly affect the biopsychosocial aspects of the people who present $i^{(8)}$, including family members, especially when chronically ill children. Thus, it is necessary to have a more active participation of nurses and other health professionals with these family members, in order to welcome them throughout the health care network, to train caregivers for home care and to clarify their doubts whenever is needed ${ }^{(11)}$.

In the literature, although some scientific data discuss the importance of health education for people with sickle cell disease and their family members, as presented above, no study was found that sought to listen to them, in order to identify their real guidance needs in the daily care of these children.

Based on the initial results of this research under development by UECE, it was possible to reach the first objective outlined, focus of this manuscript: To know the main health guidance needs of family members of children with sickle cell disease.

\section{OBJECTIVE}

To know the main health guidance needs of family members of children with sickle cell disease.

\section{METHOD}

\section{Ethical aspects}

This study began after approval by the Research Ethics Committee of the Universidade Estadual do Ceará (UECE) and the hospital setting of data collection. In compliance with the norms of Resolution 466/2012 of the National Health Council (Conselho Nacional de Saúde), the principles of respect for the individuals' autonomy, beneficence, non-maleficence and justice were ensured. Information about the purpose of the study and procedures performed were described in the Informed Consent Form, signed by all participants. To ensure anonymity, the true names of these people have been omitted, being replaced by letters and numbers. 


\section{Type of study}

The present manuscript consists of a part of a research called "Elaboration and validation of guidance booklet and follow-up on the health of people with sickle cell disease". However, prior to the construction of this technology, a qualitative approach was developed with a previous objective, which is the focus of this article. Thus, the information obtained in this first moment will act as a basis for selecting a more specific content about that portion of the population, which will help in the production of said health education technology in line with the real needs of these chronically ill people. It is a type of situational analysis/diagnosis, advocated and used by some authors ${ }^{(12-13)}$.

\section{Study setting}

This stage occurred from April to May 2017 and was developed in a pediatric reference hospital in Ceará State, specifically in the Ambulatory of Specialties, where children and adolescents with sickle cell disease of up to 18 years of age are clinically followed. It should be noted that in this service there are no health education activities on this disease.

\section{Collection and organization of data}

Family members who followed up children with sickle cell disease were approached by the researchers in the waiting room of the outpatient clinic, and sampling was done for convenience. After identifying the possible participants, the following inclusion criteria were used: to be responsible for the minor and to participate both in their treatment in health services and in home care, in order to present a greater content of details regarding the object under study; and the child has a laboratory confirmed diagnosis of sickle cell disease.

The exclusion criterion was: family members presenting some cognitive deficit, with previous medical diagnosis, that would hinder the understanding of questions asked in this research. All family members contacted accepted to participate in the study and the collection continued until reaching a degree of deepening of the information regarding the objective outlined. Thus, a total of 12 family members were obtained, none of whom had previous experiences with health education activities.

For data collection, semi-structured interviews were conducted according to a script composed of two items: family and child characterization; and guiding questions about the object being studied. The interviews took place in the waiting room itself, given the unavailability of a reserved space in the service. Not all were recorded, as some participants requested that the recorder not be used.

\section{Data analysis}

The complete transcribed material was organized in individual files and, for analysis, the steps recommended by Bardin's Thematic Categorical Analysis ${ }^{(14)}$ were followed: pre-analysis; exploitation of the material; treatment of results, inference and interpretation.

This analysis is carried out by means of operations of splitting a text into units and categories, according to analog regroupings. Thus, the researchers initially carried out a floating reading of the speeches, reorganizing them based on their similarities and disagreements on the themes in common. In the exploration stage, dialogues were established between the participants' speeches, according to the predefined themes.

In the third and last phase of process of the obtained results and interpretation, the data were treated so that they became valid and significant. In this phase, the researchers made inferences and interpretations, relating them to the initial theoretical reference, in order to highlight the main information found in the research and expose them clearly.

Thus, after the final analysis of the data with the elaboration of the central themes, three thematic categories were constructed: Knowledge of Family Members on Sickle Cell Disease; Health Guidance Needs on Chronically III Child Care; Health Rights of Children with Sickle Cell Disease.

\section{RESULTS}

\section{Characterization of Family Members and Children}

Eleven of family members interviewed were mothers of the children and one was an aunt, but the one responsible for the infant. The age of these participants ranged from 18 to 47 years. Regarding the origin, five were from the city of Fortaleza and two resided in the metropolitan region; the other localities were: Parnaíba (Piauí), Guaraciaba, Brejo Santo, Acaraú and Barbalha. As for marital status, four were married, six had a stable union, one was single and one was divorced. With regard to schooling, six had completed high school and one was in the process of completing it, two had incomplete secondary education and three had completed elementary education.

With regard to occupational activities, almost all family members did not have formal employment (10). As for family income, two did not receive financial benefit, since the income of the family was constituted by the formal employment of one of its members; six of them received one of the benefits of the government (family allowance and/or continuation benefit) and two did not receive any formal benefits or income because they had not requested or were still trying to obtain them; thus surviving only with informal incomes from other family members.

As for the children, the age ranged from 7 months to 10 years, with seven being male and five female. Regarding schooling, three were not studying because of age (under four years of age), four attended pre-school (kindergarten), four to third grade and one to fifth. Regarding the complications presented up to the moment of the interview, five did not report them; the others cited painful crises, cerebral vascular accident, pneumonia, anemia and priapism.

As for hospitalizations, only three never had to stay hospitalized and, for the others, ranged from one to more than 10 hospitalizations. Five did not need blood transfusions; the remainder required one to eight transfusions. With regard to medications, eleven children used folic acid, seven hydroxyurea, seven oral penicillins, two iron chelators, two analgesics and only one used ferrous sulfate (a seven-month-old child whose mother could not tell which type of sickle cell disease she owned). These results are consistent with the literature, since these infants may present iron deficiency and therefore should participate in clinical and laboratory follow-up to assess the need for supplementation ${ }^{(15)}$. 


\section{Knowledge of Family Members on Sickle Cell Disease}

There were divergent opinions among family members about what this pathology would be. While some were able to mention scientific definitions, in technical terms, others could not explain what it was or claimed the lack of guidance, as shown in the lines:

I understand very little, I just know that they say it's genetic, how I have the trait and her father has, she was born with this disease, could have been born all three, but only she was born, but to say that I am updated about the subject, no, I can't. (E1)

You already born with it; it is genetic, people are not informed about it, the disease could be more disclosed [...] it is genetic; the father and the mother with trait, that cannot take iron; Marrow transplant is already possible, there is risk of stroke, and many other things; The main symptom is pain. (E4)

Phrases such as "very serious", "no cure", "medical prosecution is impossible" were verbalized, which denotes understanding about the complexity of this disease and the impossibility of cure. However, this knowledge brought suffering to family members, mainly because of fear about the child's future and possibility of death, as the following testimony reveals:

It's a very serious illness and if I don't follow the treatment correctly, I would lose her very early [mother cries], they were very tough when they said it [cry], that's why they said that it's for me to take good care of her. (E1)

On the other hand, it was also possible to identify erroneous understandings on the part of family members, because some described illness forms unrelated to sickle cell disease. Two testimonies cited that, in the absence of adequate treatment, the disease could progress to leukemia:

It's kind of rare, genetic, long-lasting treatment; we have to be attentive not to turn into leukemia. (E8)

I don't know what it is; if it is not treated right it can become leukemia. (E7)

Regarding the form of access to information, some mentioned groups on the disease in social networks, as well as searches by guidance in the internet or from other family members of children with sickle cell disease:

There's a WhatsApp group, they talk a lot, they're not good at it, they exchange ideas, there are people from other locations [from other states]; there are trained people [have sickle cell disease and complete higher education], they tell their stories, because it is not easy for those who have sickle cell disease, in the market, to graduate [...]. (E4)

[...] but everything other moms talk, nothing is nobody of the hospital, nothing that we know that has here speaking like lecture, saying something of this, no.. Everything is other moms, we meet and then moms go and talk. (E6)

I research a lot in the internet [...] I have clarified my doubts because of the internet. (E2)
Also highlighted was the lack of guidelines from the health services, which is why they sought information from other sources in order to clarify their doubts about the illness of their children/relatives.

\section{Health Guidance Needs on Chronically III Child Care}

Family members cited some reasons that contributed to a feeling of unpreparedness and doubts about the disease, as well as ways to prevent and treat complications. According to them, there was, above all, a need for more guidance. The issues declared by family members as important to them, and further guidance is needed, were highlighted in the chart below:

Chart 1 - Health guidance needs of family members of children with sickle cell disease.

\begin{tabular}{|c|c|}
\hline $\begin{array}{l}\text { Guidance } \\
\text { Needs }\end{array}$ & Speeches of Participants \\
\hline $\begin{array}{l}\text { General } \\
\text { Information } \\
\text { on Illness and } \\
\text { Care }\end{array}$ & $\begin{array}{l}\text { I wish I could know everything...[how] to } \\
\text { prevent. (E1) } \\
\text { And if we really know how to do it, if we } \\
\text { have the correct guidance, it would be better } \\
\text { for us. (E3) } \\
\text { The care, what the person could feel, } \\
\text { symptoms [...]. (E5) } \\
\text { And the care, the treatment. (E8) }\end{array}$ \\
\hline Feeding & $\begin{array}{l}\text { Feeding, what we can give. (E2) } \\
\text { A lot of people don't know about feeding; } \\
\text { they say that milk is bad, but I don't think } \\
\text { so, because it improves bones and teeth. (E8) }\end{array}$ \\
\hline $\begin{array}{l}\text { Prevention and } \\
\text { Care in Pain } \\
\text { Crises }\end{array}$ & $\begin{array}{l}\text { [...] preventing pain. (E2) } \\
\text { [...] she's already feeling this pain daily, I'll } \\
\text { ask her [doctor], what I can do if this happens } \\
\text { more often; some ointment, something that } \\
\text { can happen to relieve, because it hurts too } \\
\text { much, it bothers. (E9) }\end{array}$ \\
\hline $\begin{array}{l}\text { Prevention and } \\
\text { Identification } \\
\text { of } \\
\text { Complications }\end{array}$ & $\begin{array}{l}\text { How to prevent complications [...]. (E1) } \\
\text { What he can feel, what could be worsen. (E2) } \\
\text { From what I heard she could have } \\
\text { convulsions. I wanted you to guide me more } \\
\text { about this moment, how I could act. I wanted } \\
\text { to know more or less. (E9) } \\
\text { They should be more specific, like to be } \\
\text { always paying attention in the symptoms, for } \\
\text { example. I didn't even know when she had a } \\
\text { stroke, I didn't know she could have had that } \\
\text { stroke, I didn't know. (E10) } \\
\text { I think people could talk about complications, } \\
\text { right? There are a lot of people who don't } \\
\text { know [...]. (E11) }\end{array}$ \\
\hline Health Rights & $\begin{array}{l}\text { Information that children have rights, because } \\
\text { we work, we leave these children with one } \\
\text { person and the other, because we don't get } \\
\text { the benefit so easily and they don't tell us } \\
\text { how to do it, or what rights you have or not, } \\
\text { I think there should have more information } \\
\text { about it. (E6) }\end{array}$ \\
\hline
\end{tabular}

Participants mentioned a number of issues of concern that they considered essential so that they could provide more appropriate care to their children and identify early signs and symptoms of risk. In this way, family members discussed a number of issues 
they wanted to be informed about, in order to promote better care for their children, and to be able to identify early signs and symptoms of risk situations. Concerning doubts about health rights, these aspects were best discussed in the next category.

\section{Health Rights of Children with Sickle Cell Disease}

Family members' knowledge about health rights was restricted to the Continuous Cash Benefit (BCP - Benefício de Prestação Continuada), a financial grant offered by the Government.

There is his benefit. (E3)

Only the right to salary, to my knowledge. (E4)

Some participants also demonstrated an understanding of the right to transportation to the pediatric reference service in the city of Fortaleza, for follow-up of the children, provided by the municipalities: "the Office provided transportation or ticket here" (E9). Regarding the source of guidance on these benefits, many were clarified by other family members, in the corridors of the hospital prior to consultations or by relatives and neighbors. Health professionals were also cited, but by a minority of the participants:

She told me to come and tell the doctor that she could give me a certificate so that I could go back and find out if I am entitled to this benefit. It was a neighbor of mine [who guided me on BPC]. (E9)

Everything that we know that is entitled is always some mother who already managed, when we meet, the mothers speak. (E6)

I learned about the right to benefit from her doctor, she asked if I was already receiving the aid and I said that I wasn't. (E10)

\section{DISCUSSION}

Based on the analysis of these results, it can be seen that family members' knowledge about sickle cell disease varied widely among the participants, although the majority still thought they were ill prepared to cope with the illness in the child's life, and often, present restricted understanding to the technical definition of the disease.

In their speech, the participants showed aspects related to the disease that was more related to the genetic part, changes in hemoglobins, and sickle cell trait. However, in addition to these definitions and concepts, which many only memorized but did not really understand, some did not know how to give details about the disease, its complications or necessary care, for example.

The speeches also expressed an understanding about the severity of the disease, coming from the information provided by health professionals at the time of diagnosis, which generated uncertainties. In fact, initially, the news of being an "incurable" disease generates a phase of denial and despair, which is gradually faced by experience with the disease. However, it is always a difficult process, requiring great emotional balance ${ }^{(16)}$. Thus, at the time of reporting on the disease, health professionals need to pay attention to families' longing, which often expect attention to their psychic suffering, and offer emotional support compatible with their real needs at that moment ${ }^{(17)}$.

It is important to have a better interaction between health professionals and family members, so that effective communication is established among all involved and the team perceives family as someone who needs care and has biological and psychosocial needs. Thus, care for children with sickle cell disease must transcend a strictly clinical and biomedical care, drawing attention to their family members, as they have doubts and anxieties about the illness of their children.

Some participants mentioned receiving incorrect information about sickle cell disease, associating their clinical worsening with the risk of developing leukemia, which expresses the way some have perceived this disease, based on their own conceptions, or incomprehension of the guidelines provided by professionals. In addition, it is possible that these people also associate sickle cell disease with leukemia, because both pathologies are related to blood.

A study conducted by Figueiredo and others ${ }^{(18)}$ pointed out that the guidance provided by professionals has sometimes not been adequately understood, or that they do not even perform these guidance activities. The authors pointed out the use of technical and scientific terms by the health team as a factor that has distanced professionals from family members and weakened the communication between them.

Similar to these findings, a study developed in the city of Teresina, Piauí State, with 15 family members of children with sickle cell disease, found that these people were not adequately aware of the illness of their children and, therefore, many did not give due importance to the care children, for lack of proper guidance ${ }^{(19)}$.

It is assumed that due to the absence of a health education process directed at these people at different levels of care, many have sought information and clarify their doubts on social networks, on virtual search sites or with other family members of children who have the same disease.

A survey of 380 health professionals and students in Lagos, Nigeria, identified that most had already heard about sickle cell disease, but only 93 (24.3\%) had accurate knowledge of most of the complications from it ${ }^{(20)}$. Likewise, a Brazilian study developed in Minas Gerais State with 96 Primary Health Care professionals concluded that the knowledge about sickle cell disease has been unsatisfactory for an adequate management and care of children affected ${ }^{(21)}$.

Therefore, the need to train these professionals, both for the promotion of better health care and for them to feel safer to promote health education activities for patients and their family members. The E6 speech, exposed in the first category, also explained that the participation of health professionals in the guidance process has been incipient, which reiterates the importance of the informal social network for acquiring knowledge about the disease.

Another study pointed out that the information acquired by family members of children with special health needs came from informal guidance networks or came from relatives, friends, virtual social networks and the internet. This is a worrying situation in view of the precariousness of these data, which do not have adequate scientific background ${ }^{(22)}$. 
Although the information acquired in the virtual environment represents a widely disseminated data source in society, with free and free content that can support families of chronically ill children, the quality of this information is questionable. In addition, part of the population still has limitations to access the internet ${ }^{(23)}$.

A recent study developed in the United States reaffirmed the importance of family members being present in patient care, during all stages of life relative to sickle cell disease, from childhood, youth to the transition to adulthood. In addition, he pointed out that these people have also used virtual technologies to search for data on the symptoms of this disease, among other information, which worries health professionals because they consider inaccurate data shared on the internet ${ }^{(24)}$.

However, regardless of the way this information was acquired, it was evident in this study the need for guidance to these relatives, through more active participation of health teams. On the other hand, it was identified the need to also listen to what these professionals say, to identify the most effective strategies and aspects that favor the work process and health education actions. It is known that, due to the great demands of care in Brazilian public health services and the low number of professionals (as observed in the service under study), it is often impracticable to hold guidance groups and/or moments of health education. Thus, this failure must be discussed among managers, politicians and professionals, so that it can be corrected in a feasible way for each reality, with a view to contributing to the care of these chronically ill people and their family members.

In this sense, research developed in Rio de Janeiro State reported several benefits of performing health education activities in a waiting room of a hematological reference hospital. The results showed an increase in the adherence of patients with sickle cell disease to the consultations, improved understanding about the disease, and greater approximation among patients, family members and health professionals ${ }^{(25)}$. Therefore, health education developed through different strategies must be an intrinsic part of the multiprofessional team work process and needs to be established based on the actual needs of the target audience.

Thus, based on the table presented in the results of this research, it was observed that these people have expectations of being guided, from general information about the pathology, such as the symptoms and necessary care, to more complex data related to the different types of complications that can over the years.

The fact that the participants discuss the aspects related to the prevention of pain and complications also draws attention, insofar as they expressed recognition of the need for a care that would involve them and avoid those situations that generate even greater suffering.

Although a child with sickle cell disease may appear healthy when viewed alongside others, it is known that he or she struggles daily with pain, which may arise unexpectedly ${ }^{(26)}$. Thus, it is important to guide the family about the increase in water intake, rest, the need to avoid abrupt changes in temperature and, also, regarding the correct use of drugs in the home, since they are essential measures to prevent painful crises $^{(2)}$.

Concerning complications, the participant's E10 speech, described in Chart 1, is highlighted, as it highlights the importance of family members being informed about some signs that alert the need for rapid decision-making, so that the child receives a health care and improve their clinical condition with a minimum of sequels. In this sense, Santos and others ${ }^{(19)}$ stated that family members' knowledge about the pathophysiology of sickle cell disease, because it is a chronic characteristic, is essential for a greater survival of the child.

Thus, information on risk signs should be emphasized in the guidance process, such as: acute chest syndrome, fever and infections, functional asplenia, splenic sequestration crisis, liver and gallbladder alterations, stroke, ulcers, priapism, among others.

The literature also describes many precautions to alleviate the symptoms of sickle cell disease and prevent complications. These are information that should be passed on to family members through health education, as they will benefit the daily lives of chronically ill individuals ${ }^{(27)}$.

In children, infection is the main cause of death: the chances of occurrence of sepsis or meningitis by Haemophilus influenzae or Streptococcus pneumoniae are about 600 times higher than those that do not present this pathology, evolving to death within a few hours ${ }^{(28)}$. Thus, the need to understand the attitudes to be taken in child care, evidenced in the speeches of the participants, is of significant importance, since they can prevent early deaths.

Feeding care has also been highlighted. Some described the diet offered to the child, but they showed insecurity in their speeches, since they were not sure if this would be the most adequate diet.

Although research on nutrition in the context of people with sickle cell disease is still incipient, a study by Souza and others $^{(29)}$ highlighted the importance of a nutritional follow-up of children with this disease, mainly due to the delays in growth and development physical, already evidenced in other studies, besides the increase in the metabolism. However, one participant in the study, a mother of a child with sickle cell disease, revealed little knowledge about care and factors related to nutrition, corroborating the findings on screen.

Participants also expressed lacking understanding about rights of children with sickle cell disease and stressed the importance of being enlightened about the ways to achieve them. Of the various health rights under Brazilian law, some have emphasized having or have heard of BPC. It is the right of the disabled person to receive the value of a monthly minimum wage, provided that he or she proves that he or she does not have income to provide for his or her subsistence and that it is not provided by his family members ${ }^{(30)}$; thus, the child with sickle cell disease only has access to this benefit, among other factors, if they present any deficiency coming from their illness.

National and international studies have evidenced the financial shortages of family members of chronically ill children, mainly due to the need for the primary caregiver to normally dedicate herself exclusively to the child and give up her work. In addition, health care expenditures are constant, as is the cost of going back and forth to specialized medical follow-up services ${ }^{(17,31)}$.

The right to transport to the pediatric reference health service was also mentioned, but only by a minority of the participants. This is guaranteed by the Ministry of Health in situations where the forms of treatment are exhausted in the municipality where the patient is domiciled ${ }^{(32)}$. However, although not mentioned, due to lack of use or absence of knowledge, the importance of 
this right is highlighted, especially since the pediatric reference hospital in the city of Fortaleza offers specialized follow-up to all children with sickle cell disease in Ceará State. Thus, transportation is an additional expense for family members, who need to take the children both for consultations and for treatment.

In this context, a study carried out in Bahia State pointed out the difficulties faced by people with sickle cell disease to access quality care, since they had to travel long distances and travel extensively to a specialized hematology service. In addition, the financial difficulties experienced by them, common to many Brazilians with sickle cell disease ${ }^{(33)}$.

The lack of information and understanding about public policies contributes to the population distancing itself from its rights and playing the role of citizen, intensifying its social immobility and ignorance on these issues. In addition to the lack of knowledge generated by the absence of divulgation actions, these aspects can also be explained by the low level of schooling of the population and by the lack of discussions about these issues, although they are of considerable importance in the daily lives of these people $\mathrm{e}^{(12)}$.

In fact, it has been observed that health professionals have not taken this role of guides on health rights, and so family members end up seeking information from other sources. Guiding them about the behaviors necessary to acquire them is of great importance to these children.

\section{Study limitations}

The research presented limitations in that it restricted the collection of data to family members of children with sickle cell disease, and health professionals were not included as participants in the study, which could have further enriched the discussions. It is suggested to carry out studies involving these professionals, in order to complement the findings already presented.

\section{Contributions to the sector of Health}

The discussions presented may support a more specific assistance to family members of children with sickle cell disease, as well as guiding health guidance activities based on the needs experienced by these people in the course of their experiences with childhood chronicity.

\section{FINAL CONSIDERATIONS}

The results of the present study show that family members of children with sickle cell disease receive health guidelines, but these are punctual and/or meager, so that knowledge about the disease, its symptoms and its complications has presented weaknesses. Family members recognize the severity of the pathology, but such understanding is imprecise and often comes from unreliable sources of information, such as social networking groups who discuss the disease and share experiences.

The interviewees showed a significant desire to receive more information about the disease, home care, prevention of complications, nutritional guidelines and rights in health, and further clarification regarding treatment. Knowing the disease allows to recognize warning symptoms for the onset of the sickle cell crises. In this sense, the educational technologies, such as the printed material (booklet) that will be elaborated by the researchers of this study, are of great help to transmit information to family members of children with sickle cell disease and, consequently, to improve the quality of life of these people.

Although preliminary, the results of this study allow health professionals to better target their health education activities by highlighting the main family members' guidance needs of children with sickle cell disease. In addition, they encourage these professionals to recognize themselves as agents of the guidance process, so that their care for them transcends therapeutic care.

\section{REFERENCES}

1. Gomes LMX, Pereira IA, Torres HC, Caldeira AP, Viana MB. Access and care of individuals with sickle cell anemia in a primary care service. Acta Paul Enferm[Internet]. 2014[cited 2017 Sep 20];27(4):348-55. Available from: http://www.scielo.br/pdf/ape/ v27n4/en_1982-0194-ape-027-004-0348.pdf

2. Brasil. Ministério da Saúde. Secretaria de Atenção à Saúde. Departamento de Atenção Especializada. Doença falciforme: condutas básicas para o tratamento[Internet]. Brasília: Ministério da Saúde; 2013[cited 2017 Sep 20]. Available from: http://bvsms.saude. gov.br/bvs/publicacoes/doenca_falciforme_condutas_basicas.pdf

3. Hassell KL. Population Estimates of Sickle Cell Disease in the U.S. Am J Prev Med[Internet]. 2010[cited 2017 Sep 20];38(4-Suppl):S512-21. Available from: http://www.ajpmonline.org/article/S0749-3797(09)00960-X/fulltext

4. Brousseau DC, Panepinto JA, Nimmer M, Hoffmann RG. The number of people with sickle-cell disease in the United States: national and state estimates. Am J Hematol[Internet]. 2010[cited 2017 Sep 20];85(1):77-8. Available from: http://onlinelibrary. wiley.com/doi/10.1002/ajh.21570/epdf

5. U.S. Department of Health \& Human Services. Center for Disease Control and Prevention-CDC. Sickle Cell Disease: Data e Statistics[Internet]. 2017[cited 2017 Sep 20]. Available from: http://www.cdc.gov/ncbddd/sicklecell/data.html

6. Brasil. Ministério da Saúde. Secretaria de Atenção à Saúde. Departamento de Atenção Hospitalar e de Urgência. Doença falciforme: diretrizes básicas da linha de cuidado[Internet]. Brasília: Ministério da Saúde; 2015[cited 2017 Sep 20]. Available from: http:// bvsms.saude.gov.br/bvs/publicacoes/doenca_falciforme_diretrizes_basicas_linha_cuidado.pdf

7. Humphries C. Drug development: a complicated path. Nature[Internet]. 2014[cited 2017 Sep 20];515(7526):S4-5. Available from: https://www.nature.com/nature/journal/v515/n7526_supp/pdf/515S4a.pdf

8. Rocha LP, Cioff ACS, Oliveira DP. Assistência de enfermagem frente à problemática clínica de pacientes portadores de anemia 
falciforme. Rev Eletrôn UNIVAR[Internet]. 2014[cited 2017 Sep 20];2(12):44-8. Available from: http://www.scielo.br/pdf/rbhh/ v29n3/v29n3a27.pdf

9. Fernandes APPC, Januário JN, Cangussu CB, Macedo DL, Viana MB. Mortality of children with sickle cell disease: a population study. J Pediatr[Internet]. 2010[cited 2017 Sep 20];86(4):279-84. Available from: http://www.scielo.br/pdf/jped/v86n4/en_a06v86n4.pdf

10. Shahine R, Badr LK, Karam D, Abboud M. Educational intervention to improve the health outcomes of children with sickle cell disease. J Pediatr Health Care[Internet]. 2015[cited 2017 Sep 20];29(1):54-60. Available from: https://www.ncbi.nlm.nih.gov/ pubmed/25115311

11. Figueiredo SV, Sousa ACC, Gomes ILV. Children with special health needs and family: implications for Nursing. Rev Bras Enferm[Internet]. 2016[cited 2017 Sep 20];69(1):88-95. Available from: http://www.scielo.br/pdf/reben/v69n1/en_0034-7167-reben-69-01-0088.pdf

12. Caetano R, Garrafa V. Comunicação como ferramenta para divulgar e promover a Declaração Universal sobre Bioética e Direitos Humanos. Rev Bioét[Internet]. 2014[cited 2017 Sep 20];22(1):34-44. Available from: http://www.scielo.br/pdf/bioet/v22n1/ a05v22n1.pdf

13. Reberte LM, Hoga LA, Gomes ALZ. O processo de construção de material educativo para a promoção da saúde da gestante. Rev Latino-Am Enfermagem[Internet]. 2012[cited 2017 Sep 20];20(1):[8 telas]. Available from: http://www.scielo.br/pdf/rlae/v20n1/pt_14

14. Bardin L. Análise de conteúdo. Tradução Luís Antero Reto, Augusto Pinheiro. São Paulo: Edições 70; 2011.

15. Rodrigues PC, Rocksane CN, Murao M, Januario JN, Viana MB. Iron deficiency in Brazilian infants with sickle cell disease. J Pediatr[Internet]. 2011[cited 2018 Mar 03];87(5);405-11. Available from: http://www.scielo.br/pdf/jped/v87n5/en_v87n05a07.pdf

16. Gesteira ECR, Bousso RS, Rodarte AC. Uma reflexão sobre o manejo familiar da criança com doença falciforme. Rev Enferm Cent O Min[Internet]. 2016[cited 2017 Sep 20];6(3):2454-62. Available from: http://www.seer.ufsj.edu.br/index.php/recom/article/ view/758/1178

17. Gomes GC, Nornberg PKO, Jung BC, Nobre CMG, Rodrigues EF, Xavier, DM. Doença crônica na criança: vivências da família no recebimento do diagnóstico. Rev Enferm UFPE[Internet]. 2016[cited 2017 Sep 20];10(6):4837-44. Available from: http://www. revista.ufpe.br/revistaenfermagem/index.php/revista/article/view/10693/pdf_2000

18. Figueiredo SV, Gomes ILV, Pennafort VPS, Monteiro ARM, Figueiredo JV. Therapeutic communication between health professionals and mothers accompanying children during inpatient treatment. Esc Anna Nery[Internet]. 2013[cited 2017 Sep 20];17(4):690-7. Available from: http://www.scielo.br/pdf/ean/v17n4/en_1414-8145-ean-17-04-0690.pdf

19. Santos LRO, Rocha SS, Costa RS, Araújo OD, Gouvéia MTO, Araújo AKL. Contribuições da enfermagem para os cuidados da criança com doença falciforme. Teresina: EDUFPI, 2015. p. 97-110.

20. Animasahun BA, Akitoye CO, Njokanma OF. Sickle cell anaemia: Awareness Among Health Professionals and medical students at the Lagos University Teaching Hospital, Lagos. Nig Qt J Hosp Med[Internet]. 2009[cited 2017 Sep 20];19(4):195-99. Available from: https://www.ncbi.nlm.nih.gov/pubmed/20836330

21. Gomes LMX, Vieira MM, Reis TC, Barbosa TLA, Caldeira AP. Knowledge of family health program practitioners in Brazil about sickle cell disease: a descriptive, cross-sectional study. BMC Family Pract[Internet]. 2011[cited 2017 Sep 20];12(89). Available from: https://bmcfampract.biomedcentral.com/articles/10.1186/1471-2296-12-89

22. Figueiredo SV, Gomes ILV, Queiroz MVO, Mota DDS, Sousa ACC, Vasconcelos CMP. Families' knowledge about children and adolescents with neural malformation about their rights in health. Esc Anna Nery[Internet]. 2015[cited 2017 Sep 20];19(4):671-8. Available from: http://www.scielo.br/pdf/ean/v19n4/en_1414-8145-ean-19-04-0671.pdf

23. Mazza VA, Lima VF, Carvalho AKS, Weissheimer G, Soares LG. Online information as support to the families of children and adolescents with chronic disease. Rev Gaúcha Enferm[Internet]. 2017[cited 2017 Sep 20];38(1):e63475. Available from: http:// www.scielo.br/pdf/rgenf/v38n1/en_0102-6933-rgenf-1983-144720170163475.pdf

24. Frost JR, Cherry RK, Oyeku SO, Faro EZ, Crosby LE, Britto M, et al. Improving Sickle Cell Transitions of Care Through Health Information Technology. Am J Prev Med[Internet]. 2016[cited 2017 Sep 20];51(1S1):S17-S23. Available from: http://www. sciencedirect.com/science/article/pii/S074937971600060X

25. Carvalho EMMS, Santo FHE. Papel da educação em saúde no cuidado a pessoas com doença falciforme - relato de experiência. Interd Rev Eletrôn Univar[Internet]. 2015[cited 2017 Sep 20];2(14):79-82. Available from: http://revista.univar.edu.br/index.php/ interdisciplinar/article/view/440/366

26. Nogrady B. Neurobiology: life beyond the pain. Nature[Internet]. 2014[cited 2018 Mar 08];515:S8-S9, 2014. Available from: https://www.nature.com/articles/515S8a

27. Baptista TF, Morais AC, Ferreira CLC. Con(vivendo) com anemia falciforme: o olhar da enfermagem para o cotidiano de adolescentes. In: Ferreira SL, Cordeiro RC. Qualidade de vida e cuidados às pessoas com doença falciforme. Salvador: EDUFBA; 2013. p. 75-94.

28. Soares AB, Gobbi DR, Silva GD, Siqueira ICGL, Cruz MP. A assistência de enfermagem em crianças e adolescentes portadores de anemia falciforme. Rev Recien[Internet]. 2012[cited 2018 Mar 08];2(5):5-10. Available from: http://www.recien.com.br/index. php/Recien/article/view/36

29. Souza KCM, Damião JJ, Santos LCS, Santos MR. Acompanhamento nutricional de criança portadora de anemia falciforme na Rede de Atenção Básica à Saúde. Rev Paul Pediatr[Internet]. 2008[cited 2017 Sep 20];26(4):400-4. Available from: http://www.scielo. 
br/pdf/rpp/v26n4/a15v26n4.pdf

30. Brasil. Decreto $n^{\circ} 6.214$, de 26 de setembro de 2007. Regulamenta o benefício de prestação continuada da assistência social devido à pessoa com deficiência e ao idoso de que trata a Lei no 8.742 e a Lei no 10.741, acresce parágrafo ao art. 162 do Decreto no 3.048 e dá outras providências[Internet]. Diário Oficial da República Federativa do Brasil[Internet]. 2007[cited 2017 Sep 20]. Available from: http://www.planalto.gov.br/ccivil_03/ ato2007-2010/2007/decreto/d6214.htm

31. Yawson AE, Abuosi AA, Badasu DM, Atobra D, Adzei FA, Anarfi JK. Non-communicable diseases among children in Ghana: health and social concerns of parent/caregivers. Afr Health Sci[Internet]. 2016[cited 2017 Sep 20];16(2):378-88. Available from: http:// www.bioline.org.br/pdf?hs16051

32. Brasil. Ministério da Saúde. Portaria nº55 de 24 de fevereiro de 1999. Dispõe sobre a rotina do Tratamento Fora de Domicílio no Sistema Único de Saúde - SUS, com inclusão dos procedimentos específicos na tabela de procedimentos do Sistema de Informações Ambulatoriais do SIA/SUS e dá outras providências. Diário Oficial da República Federativa do Brasil[Internet]. 1999 fev. 24[cited 2017 Sep 20]. Available from: http://bvsms.saude.gov.br/bvs/saudelegis/sas/1999/prt0055_24_02_1999.html

33. Silva HD, Paixão GPN, Silva CS, Bittencourt IS, Evangelista TJ, Silva RS. Anemia falciforme e seus aspectos psicossociais: o olhar do doente e do cuidador familiar. Rev Cuid[Internet]. 2013[cited 2018 Mar 08];4(1):475-83.Available from: http://www.scielo. org.co/pdf/cuid/v4n1/v4n1a07.pdf 